\title{
Koca Nişancı Celâlzâde Mustafa Çelebi ve Eserlerine Toplu Bir Bakış
}

\section{A Look at the Life and Works of Koca Nişancı Celâlzâde Mustafa Çelebi}

\section{Coşkun KUMRU*}

Öz: Osmanlı İmparatorluğu'nun tartışmasız en ihtişamlı dönemini yansıtan Kanuni Sultan Süleyman'ın saltanatı, muhteşem zaferlerin yanı sıra imparatorluk bürokrasisinin gelişimini ve kanun-devlet ilişkisini yansıtması bakımından da dikkate değerdir. Şüphesiz Sultan Süleyman'ın Kanunî unvanını kazanmasında büyük hukuk adamları Ebûsuud ve Kemalpaşazâde Efendilerin yanında devrin kanunlarını düzenleyen Koca Nişancı olarak bilinen Celâlzâde de önemli katkılarda bulunmuştur. Osmanlı İmparatorluğu'ndaki değişimlere bağlı olarak gelişen bürokratik yapı Celâlzâde ile birlikte en parlak konumuna yükselmiştir. Onun kullandığı hitaplar ve ifade biçimleri Osmanlı bürokrasisindeki etkisini en az 17. yüzyılın ilk çeyreğine kadar sürdürmüştür. Kendisi üst düzey bir bürokrat olmanın yanında aynı ölçüde bir âlim, tarihçi ve de şairdir. Eserleri bulunduğu döneme ait kaynakların en değerlilerindendir. Devlet kademelerindeki tecrübesi ve tanık olduğu olaylar kendisine imtiyazlı bir konum kazandırmış ve bu durum kaleme aldığı eserlerin kıymetini de arttırmıştır. Makalede söz konusu yazarın hayatı ve eserleri hakkında toplu bir malumat verilecektir.

Anahtar sözcükler: Osmanlı İmparatorluğu, Nişancı, Celâlzâde Mustafa Çelebi, Bürokrasi, Kanun, Kanuni Sultan Süleyman.

Abstract: Kanuni Sultan Süleyman's reign surely reflects the most glorious period of the Ottoman Empire, due to great victories and the noteworthy development of the imperial bureaucracy and law-state relationship. It is surely beyond doubt that Ebûsuud and Kemalpaşazâde, as known legal experts and Celâlzâde, also known as Koca Nişancı regulating the laws of the period, made significant contributions in Sultan Süleyman's taking the title Kanuni. The developed bureaucratic structure resulting from the changes in the Ottoman State raised its position to the brightest together with Celâlzâde, and the forms of expressions he used continued to impact upon the Ottoman bureaucracy at least until the first quarter of the seventeenth century. In addition to being a senior bureaucrat, he was to the same degree a scholar, a historian and a poet. His works are some of the most valuable sources for his period. His experience at state level and being a witness to events gave him a privileged position and this has increased the value of the works he produced. This article provides information concerning the author's life and his works.

Keywords: Ottoman Empire, Nişancı, Celâlzâde Mustafa Çelebi, Bureaucracy, Law, Kanuni Sultan Süleyman.

Osmanlı bürokrasisi, devlet idaresine sadece etkili araçlar sağlamakla kalmamış, Osmanlı siyasi anlayışının oluşumunda da önemli bir rol oynamıştır. Celâlzâde bir anlamda Osmanlı hukukunun koruyucusu konumunda bulunmakla, kanun devleti olarak sinırları belirlenen Osmanlı Devleti'nin dinamiklerinin meşru zemine oturtulması bağlamında hizmet göstermiştir. Bu bakımdan Celâlzâde üst düzey bir bürokrat olarak dikkat çekmektedir. Kendisi devlet bürokrasisindeki öneminin yanı sıra tarihe ve ahlâka dair eserleriyle de tanınmaktadır. Makalede Celâlzâde

\footnotetext{
* Arş.Gör., Pamukkale Üniversitesi, Fen-Edebiyat Fakültesi,Tarih Bölümü, Denizli, ckumru@pau.edu.tr
} 
Mustafa Çelebi'nin yaşamına ve eserlerine dair dağınık halde bulunan bilgileri, devrin kaynakları 1şı̆̆ında toplu bir biçimde vermek amaçlanmıştır.

\section{Hayatı:}

Celâlzâde Mustafa Çelebi, devrin kaynaklarının müştereken işaret ettiği üzere Tosya'da (Günümüzde Kastamonu İli’nin bir ilçesi olan Tosya, XVI. yüzyılın başlarında Rum Eyaleti'nin bir parçası olan Çankırı Livası'na bağlı bir kaza idi, bkz. Pitcher, 2013, Harita XXV) doğmuştur (Peçevi, 1283, 43; Latîfî, 1314, 335; Beyânî, 2008, 210; Kınalızâde Hasan Çelebi, 2009, 363). Mustafa Çelebi'nin babası Kadı Celâlüddin "eşraf-ı kuzzat"tan idi. Medreseden yetişerek Rumeli tarafındaki kazalarda kadılık etmiş ve derecesi bu rütbeye yükseltilmişti. Daha sonra kendisi kadılıktan çekilerek günde otuz beş akçe ile emekli olmuş ve 935/1528 tarihinde vefat etmişti. Kadı Celâlüddin doğru ahlâkı ve mütevaziliği ile de nâm salmış ve sevilen bir kişi olarak tanınmıştır (Uzunçarşılı, 1958, 392). Kendisinin Mustafa, Salih ve Ataullah adlarındaki üç oğlunun en büyüğü Mustafa Çelebi'dir. Bu makalede ayrıca bir malumat verilmeyecek olan Salih Çelebi, tarih, kelâm, fikıh ve belâgate dair on dört kadar eseri olan çok değerli bir âlimdir. Ayrıca İbn Kemal ve Kanuni'nin hocası Hayreddin Efendi'den dersler almış, müderrislik ve kadılıkta bulunmuştur (Uzunçarş111, 1988a, 234-235). Mustafa Çelebi'nin doğum tarihi kesin olarak bilinmemekle beraber kendisi Selimnâme adlı eserinde 964/1557 yılında nişancilıktan emekli olduğunda yaşının yetmişe yaklaştığını belirttiğine göre 895-896/1490-1491 yıllarında doğmuş olduğu tahmin edilmektedir (Celâlzâde Mustafa Çelebi, 1990, 250). Şeyh Hamdullah'ın son zamanlarında, babası Celâl ve kardeşi Salih ile beraber, kendisinden yazı öğrenmiştir (Uğur, 2001, 286). Tahsilini ise Sahn-1 Seman medresesinde danişmendliğe kadar sürdürdükten sonra 922/1516'da Veziriazam Pirî Mehmed Paşa ile Nişancı Seydi Bey'in himâyesiyle medrese hayatını da bırakarak Divân-1 Hümâyun katipliğine tayin edilmek suretiyle devlet hizmetine girmiştir. Yavuz Sultan Selim, devlet erkânından gizli tutmak istediği birtakım konuları Mustafa Çelebi'yi çağırtarak bizzat ona yazdırırdı. Celâlzâde padişahın bizzat yazdırdığı fermanlardan usule aykırı olduğunu düşündüğü yerleri belirtmekten de çekinmezdi:

“Sultân Selîm Hân-ı kadîm vüzerâdan mahfî etrâfa ba'zı ahkâm u avâmir
göndermelü oldukda bana yazdırırdı. Ba'zı umûrda muhâlefet şeklin
gösterüp münâsib olan böyle eylemekdür pâdişâhum der idüm. Bir iki
def'a ıbrâkvâr-ı âd idüb izhâr-ı gazab iderdi. Ben makarr olup sa'âdetlü
pâdişâhum fermân senündür. Ammâ sa'âdetlü sâhib-i kırâna münâsib
olan budur didüğüm gibi münbasit olup imdi öyle yaz der idi”" (Beyânî,
2008, 210). Anlaş1lyor ki Celâlzâde, Sultan Selim'in yazı işlerindeki en
önemli yardımcısıdı.

Celâlzâde Mustafa, Pirî Mehmed Paşa'nın altı yıl müddetle tezkireciliğini yapmıştır. Büyük hâmîsi olan Paşa'nın 1523 yılında emekliye ayrılmasıyla usullere aykırı bir biçimde yerine İbrahim Paşa Veziriazam olmuş ve Celâlzâde'yi geniş bilgi ve becerisi sebebiyle aynı hizmette değerlendirmiştir (Kerslake, 1993, 260). Yeni Veziriazam devlet adamları içinden yetişmeyip saraydan çıktığı için devlet işlerinde acemi idi. Bu sebepten Celâlzâde Mustafa, Nişancı Seydi Bey'in tavsiyesiyle İbrahim Paşa'ya da tezkireci olmuştu. Bu durumu Beyânî, Celâlzâde'den naklen Şu'arâ tezkiresinde şöyle anlatıyor:

“... sonra Maktûl İbrâhîm Paşa harem-i Pâdîşâhîden def'aten vezir-i âzamlığa çıkdukda küttâbdan bir gâyetle ehl-i vukûf kimesne isteyüp hakîri getürüp tezkireci idindi. Kendünün ahvâli âleme vukûfi yok şikâyetçi ise izdihâm ider. Mâ-beynimüzde tenhâda ittifak olınmışdur ki eğer 
şerîka müte'allik nesne ise benüm işâretümle kâzî'askere sala eğer mâl-i pâdişâhîye müte'allik ise defterdâra göndere eğer kendüye vezârete müte'allik ise ben devât u kaleme yapuşurum. Ol dahi hükm yazılsun diyü buyururdı" (Beyânî, 2008, 210). Görülüyor ki, yeni Veziriazama devlet işlerini yürütmede ve halkla olan münasebetlerinde yardımcı olan Celâlzâde bürokraside önemli bir boşluğu doldurmuştur.

Yavuz Sultan Selim tarafindan Misır'ın fethinden sonra burada uygulanan Osmanlı kanunları ile halk ağır bir vergi yükü altına girmiş ve sonraları ciddi bir huzursuzluk baş göstermişti. Bu durumdan yararlanan birtakım Çerkes beyleri isyan etmek vasıtasıyla Çerkes kölemen ocağını yeniden tüttürmek istemişti. İşte bu şikayet ve huzursuzlukları yerinde araştırmak ve çözüm getirmek üzere Veziriazam İbrahim Paşa'nın Mısır'a gitmesine gerek görülmüştür (ayrıntılı bilgi için bk. Demir, 2014, 97-114). Tezkirecisi Celâlzâde'yle birlikte oldukça kalabalık bir maiyet ve beşyüz kadar yeniçeri ile ve deniz yoluyla 930/1524 yılında hareket etmişlerdir (Uzunçarş1lı, 1958, 394-395). Mevsim sohbahar olduğu için yoğun firtına ve rüzgarlar sebebiyle ancak Rodos önlerine ve Marmaris taraflarına kadar gidilip oradan da kara yoluyla Suriye üzerinden Misır'a varılmıştır (Detaylı bilgi için bk. Celâlzâde Mustafa Çelebi, 2011, 99-106). Veziriazam İbrahim Paşa buradaki incelemeleri neticesinde hem hazineye hem de halka zarar vermeyecek şekilde âdilâne bir kanun düzenletmiş ve bu kanunun derlenmesinde Celâlzâde'nin büyük hizmetleri olmuştur:

"Mukaddemâ İbrâhîm Paşaya kâtibi-i sır olup vezîr-i merkûm diyâr-ı Misriyyeye gitdükde baht- $u$ 'izzet gibi yaninca revân ve devlet ü şevket misâli hem 'inân olup nazar-ı iksîr te'sîriyle günden güne hilâl misâl terâkkide ve her menzilde kârbân-ı lutf u ihsânını telakkîde olup vezîr-i mezbûrun mâbihü'l- istizhârı ve kâr-ı ıslâh-ı memâlik-i islâmda mü'temen ü müsteşârı idi" (Kınalızâde Hasan Çelebi, 2009, 363). Kendisinin kariyeri açısından Mısır memuriyetinin bir dönüm noktası olduğu açıktır. Buradaki muvaffakiyeti kendisine olan itimadın artmasına ve yeni görevlendirmelere zemin hazırlamıştır.

Mısır 1slahâtı sırasında İstanbul'da meydana gelen bir Yeniçeri isyanına karıştı̆̆ tespit edilen Reisülküttab Haydar Çelebi, Kanuni'nin emriyle idam edilmiş, ondan boşalan makama İbrahim Paşa'nın dönüşü itibariyle Celâlzâde Mustafa tâyin edilmiştir (931/1525). Bununla beraber İstanbul'a gelmeden evvel 930/1524 tarihinde Reisülküttab olduğu şeklinde bir rivayet de bulunmaktadır (Danişmend, 1948, 451). Tâyin kararında Celâlzâde'nin Mısır'da Hain Ahmed Paşa'nın sebebiyet verdiği karışıklar sonrasında, asayişin temini ve yeni nizâmlar konulmasında Veziriazam'ın yanında gösterdiği üstün liyakat etkili olmuştur (Gökbilgin, 2001, 61). Bu vazifede de oldukça başarılı olan Mustafa Çelebi'nin inşâsındaki (İnşâ: İyi yazmak usulü yerinde kullanılan bir tâbirdir. İyi yazılmış yazı örneklerini içeren eserlere de bu ad verilmektedir, bkz. Pakalın, 1983, 73-74) üstünlük bilindiğinden, daha nişancı olmadan önce, öneme haiz olan bazı Nâme-i Hümayûnlar, fermanlar ve beratlar da kendisine yazdırılırdı.

Celâlzâde, on yıl süreyle Reisülküttab’lık hizmetinde bulunup seferlere iştirak ettikten sonra Kanuni Sultan Süleyman'ın Irakeyn (Irak-1 Acem ve Irak-1 Arab) seferinde bulunmuştur. Bağdat'a girildikten üç gün sonra toplanan divân kararıyla da Nişancı Seydi Bey'in vefâtı üzerine boşalan Nişanc1lık makamına tâyin edilmiştir (941/1534). Bu memuriyet kendisine seleflerinden farklı olarak sonraları 300 bin akçeye çıkarılan haslar ile verilmiştir (Mehmed Cemaleddin, 2003, 41). XVI. yüzyılın ilk çeyreğine ait maaş kayıtlarına göre Nişancı'nın hükmü altında, maaşları yedi ile otuz üç akçe arasında değişen on bir kâtib bulunmaktadır. Bu durumda da 
ortalama maaş on dokuz akçe olmaktaydı. Tarih olarak 900/1494'e kadar uzanan daha önceki bir kaynağın gösterdiğine göre, beş divan katibi bulunmakta ve onların aylık maaşlarının toplamı iki bin iki yüz doksan akçeyi bulmaktaydı (Yılmaz, 2006, 40-41). Bu açıklamalara ilaveten Celâlzâde'nin bulunduğu nişancılık makamının önemini daha iyi anlamak ve değerlendirebilmek için Nişancılık hakkında biraz malumat vermek gereklidir.

Bilindiği üzere Nişancılık, Osmanlı Klasik Dönemi’nin en yüksek memuriyetlerden biridir. Hükümdarların alâmetlerini taşıyan fermân ve beratlara Türklerde "nişan" adı verildiğinden bu alâmeti çekmeye izinli makam sahibine de "Nişancı" denilmiştir. Kanunlarla merasimi en iyi bilen nişancılar olduğu için bunlarla alakalı hususlar nişancılardan sorulur ve görüşleriyle hareket edilirdi (Pakalın, 1983, 697-700). Yeni konan kanunlarla önceki kanunları şer'i ve hukuki kanunlarla telif etmek kudret ve yetkisini elinde bulunduran ve Divân-1 Hümayûn toplantılarında ve hususî müzakerelerde bu hususlar hakkında fikir ve görüşlerinden istifade edilen, devlet kanunlarına ait hükümleri yazan, vezirlere ve devlet ricâline verilen menşur ve beratları bizzat yazan veya müsveddelerini kontrol ederek pâdişâhın ismini içeren tuğrayı çekmek yetkisini taşıyan bu görevliye Nişancı, Tevkii veyahut Tuğraî denilmiştir. Hizmeti olan nişanc1lığa da "Tuğray-ı şerîf" hizmeti adı verilmiştir. Bunlar dışında nişancının mühim hizmetlerinden biri de memleketin tahrir defterlerindeki has, zeamet, timar, vakıf, mülk arazi üzerinde yapılacak değişikliklerin mutlak şekilde nişancının kalemiyle yapılmasının kanun olması idi. Nişancı, tahrir defterleri üzerinde yapacağı düzeltmeleri Divan-1 Hümayûn'da vezirlerin huzurunda bizzat kendi kalemiyle yapar ve o sirada divanda bulunan vezirlerin isimlerini zikretmek suretiyle defterdeki yer veya ismin üzerine açıklama yapardı (Uzunçarşı1ı, 1958, 396). XV. ve XVI. asırlar boyunca nişancılığın devlet teşkilatı içerisinde önemli bir konuma sahip oluşunu da kalemiyye sınıfının en üst mertebelerinden biri sayıldığına bağlamak mümkündür (Akgündüz, 1994, 11).

Celâlzâde nişancılıkta yirmi üç sene kalmış ve asıl şöhretini bu çeyrek asırda kazanmıştır. Devlet kanûnlarında tek merci olmuş, hatta kendisini yetiştiren Seydi Bey'den daha fazla şöhret bulmuştur. Devlet idaresine ilişkin tüm kanunlar onun elinden geçmiş ve en önemlisi onun tedbirleriyle çözülmüştür. Kanunnâmedeki tâbir üzere hakkıyla "Müfti-i Kanun" olup Koca Nişanc1 diye şöhret kazanmıştır (Uzunçarş111, 1958, 397). Hatta Veziriazam İbrahim Paşa'nın Seraskerlik Beratı dahi onun inşâsıyla yazılmıştır (Seraskerlik Beratı sureti için bk. Feridun Bey, 1265, 544546).

Yukarıda belirtildiği gibi yirmi üç senelik yüksek hizmeti sonrası 964/1557 yılında bir rivâyete göre Vezir Damat Rüstem Paşa'nın entrikası nişancılıktan çekilmesine sebep olmuştur. Rüstem Paşa nişancılıktan çekilecek olursa yerine divân katipliğinde bulunan oğlu Mahmud Beyi nişancı yapacağını vaadetmişti. Fakat çağdaşı bulunan Aşık Çelebi ve sonraları Ataî, bizzat kendisinin nişancılıktan istifa ederek emekliye ayrıldığını kaydetmektedir (Gökbilgin, 2001, 62). Yine Ahmed Resmi Efendi, Halifetü'r-Rüesa isimli eserinde Rüstem Paşa'dan bahsetmeyerek Celâlzâde'nin kendi isteğiyle emekli olduğunu yazmaktadır (Ahmet Resmi Efendi, 1269, 5). Ayrıca belirtmek gerekir ki Celâlzâde de bir eserinde bu durumu teyit etmektedir. Kendisi nişancılık vazifesinden ayrılırken Kanuni Sultan Süleyman, bu zamana kadar yaptığı hizmetleri takdir ederek nişancılık haslarının emeklilik maaşı gibi kendisine bırakılmasını emretmiştir (Gökbilgin, 2001, 62). Esasen Sultan Süleyman her daim Celâlzâdenin hizmetlerini takdir etmiş ve ondan büyük bir memnuniyet duymuştur. Kendisi nişancı bulunduğu tarihte defterdarllğa tâyin edilen Nevbahar-zâde, kanunda belirlendiği üzere davet ve merasimlerde nişancidan önce gelmesi gerekirken daha evvel Koca Nişancı'nın karşısında divittarlık yaptığından eski efendisinin protokolde önünde yer almak istemeyerek "Ben dün karşısında el kavuşturup hizmet ettiğim velînimetim olan Mustafa Çelebi'ye takaddüm edemem, isterlerse azletsinler” demiştir. Kanuni 
Sultan Süleyman bu meseleyi işitince gayet memnun olarak bundan böyle divânda nişanc1 ve defterdarlardan hangisi kıdemli ise onun protokolde önde olmasını istediğinden Koca Nişancı, defterdarın önüne geçirilmiş ve bu durum kanun halini almıştır (Uzunçarş111, 1988b, 222). Celâlzâde de çok sevdiği Padişahı Kanuni'yi şu şekilde anlatmıştı:

“Onun adil davranışları ıtri yeryüzünün dört bir köşesine yayıldl; insanlar onun cömertliğinin bu hoş kokusunu ciğerlerine çektiler; adilliği herkesin dilindeydi; reayayı koruma kaygısı çok açıktı" (Woodhead, 2002, 166).

Mustafa Çelebi yine de devlet hizmetinden tamamen ayrılmış değildi. Emekliliği sırasında on sene müddetle müteferrikabaş1lı (Mütefererrika, Hükümdarla vezirlerin ve diğer hizmet sahiplerinin maiyetinde bir nevi hizmetli olan bir kısım hizmet erbabı hakkında kullanılan tâbirdir. Müteferrikabaşı da bu görevlilerin amiri pozisyonunda olan kişidir. Bk. Pakalın, 1983, 637) görevini yerine getirdi (Bursalı Mehmed Tahir, 1342, 37). Fakat yerine oğlu tâyin edilmeyerek yine değerli bir kimse olan Eğri Abdi-zâde Mudurnulu Mehmed Bey tâyin olunmuştu. Koca Nişancı emekli olduktan sonra Eyyüp'teki konağına çekilerek zamanını ilmi çalışmalara ayırmış, telif ve tercüme faaliyetlerine girişerek ibadetle meşgul olmuştur. Ayrıca Eyüb'te Nişancılar câmii ve bir konak inşâ ettirmiştir (Kınalızâde Hasan Çelebi, 2009, 363).

Sultan Süleyman'ın son seferi olan meşhur Sigetvar Seferi'ne müteferrikabaşı olması sebebiyle katılan Celâlzâde, nişancı olarak hizmet veren Eğri Abdi-zâde Mehmed Bey'in vefâtı üzerine Sokollu Mehmed Paşa'nın da işaret etmesi sonucu 974/1566 tarihinde ikinci defa nişancrlık vazifesine getirilmiştir (Selânikî Mustafa Efendi, 1999, 38; Gelibolulu Mustafa Âlî, 2009, varak 370a). Kendisinin bu göreve tâyini esnasında Sultan Süleyman vefât etmiş fakat bu durum gizli tutulduğundan kimselere duyurulmamıştı. Celâlzâde de padişahın vefâtından habersiz bir şekilde nişancılık hil'atını giymek ve Padişahın elini öpmek için Otağ-1 Hümayûna girdiğinde, Padişahının tabutunu görünce ağlamaklı olmuş, fakat Sokollu Mehmed Paşa'nın uyarısıyla durumu belli etmemek için dişarıya güler bir halde çıkmıştır (Uzunçarşı11, 1958, 399; Mehmed Süreyya, 1996, 1201). Celâlzâde ordu ile beraber İstanbul'a dönmüş ve yeni padişah II. Selim'in saltanatı zamanında on ay süre nişancılık vazifesinde bulunduktan sonra 975 rebiulahir ve 1567 Ekim'de yaklaşık yetmiş beş ile seksen yaşları arasında vefât etmiştir (Uzunçarşılı, 1958, 399). II. Selim'in Açe Padişahı Sultan Alâeddin'e gönderdiği ve Celâlzâde tarafindan yazılmaya başlanan Nâme-i Hümâyun ise sonraları başkası tarafından tamamlanmıştır (Gökbilgin, 2001, 62). Mezarı Eyüp'te yaptırmış olduğu caminin bahçesine daha önce vefat etmiş olan kardeşi Salih'in kabrinin yanına defnedilmiştir. Mezar bugün İstanbul'da Eyüp semtinde Nişancı Câmi hazîresinde görülebilir. Vefâtı hakkında Deli Kadı'nın söylemiş olduğu manzum tarih, mezar taşına şu şekilde yazılmıştır:

\author{
Celâl oğlu nişâni ki cihânın \\ Fenâsin gördü azmetti bekaya \\ Ten-i hâki olup aslina râci \\ Karıştı ruh-i pâki esfiyaya \\ Yeri cennet ola deyu melekler \\ Feleklerden el açtılar duâya \\ İsitip ruh-ı kudsi dedi târih \\ İlâhi rahmet eyle Mustafa'ya (Uzunçarş111, 1958, 399).
}

\title{
Bürokrasideki Önemi ve Kişiliği:
}

Şüphesiz Osmanlı Bürokrasisi'nin gördüğü en seçkin şahsiyetlerin başında gelen Celâlzâde 
Mustafa Çelebi yirmi üç yıl aralıksız süreyle Nişancı olarak Kanuni Süleyman'a hizmet etmiş, zamanla standart hale gelen diplomasi dilini ve nişancılık uygulamasını büyük ölçüde belirleyen bir kişi olmuştur. Şu husus çok açıktır ki, görevi süresince gerek padişahtan gerekse çevresinden gördüğü itibar en yüksek düzeyde olmuştur: "Hazret-i Padişah-ı Sâhip kıran huzur-ı şerîfinde bunlara olan itibâr nesl-i Osman'da bir nişancıya olmamışdur" (Sehi Bey, 1325, 33). Bilindiği üzere nişancı sadece padişah fermanlarına tuğra çeken bir kişi olmanın ötesinde diplomatik bilgisiyle örfî hukukun da başıdır. Bu yönüyle ona "Müfti-i Kanun" adı verilmiştir. Bu unvanın kazanılmasında Celalzade Mustafa Efendi'nin üstün çalışmaları büyük rol oynamıştır. Örfî kanunları iyi bilmek ve gerektiğinde divanda fikir beyan etmek en temel görevlerindendi. Sağlam bir medrese eğitimi alan Celâlzâde, Osmanlı Örfi Hukuku'nun temelini oluşturan kanunların yalnız birbiriyle değil, aynı zamanda şeriatla bağdaşmaları yolunda ciddi bir emek vererek bu hususta devrin Şeyhülislamı ve büyük hukuk adamı Ebussuûd Efendi ile de işbirliği içerisinde olmuştur (Kerslake, 1993, 261). Ayrıca onun inşa adı verilen edebi düz yazıdaki ustalığı da bilinirdi. Divânda yazılan önemli yazışmaların büyük bölümü ona aittir: “...nice tahrirâta sa'y itdi hâlâ divânda yazılan elkâb ve inşâa-i ekseri bunlarındur” (Peçevî, 1283, 43). Daha önce de bahsedildiği gibi Veziriazam İbrahim Paşa için kaleme aldığı Seraskerlik menşurunun yanında Safevi hükümdarı Şah Tahmasb'a yazılan nâme-i hümayûn da onun kalem gücünün en parlak örneklerindendir (Tahmasb'a yazılan Nâme-i Hümayûn örneği için bk. Feridun Bey, 1265, 541-543). Yine onunla çağdaş bir şahsiyet olan büyük divân şairi Latifî, meşhur tezkiresi'nde Celâlzâde'nin ilim ve kalemini şu şekilde övmektedir:

"Deryâ-yı fazl u irfân ve maârif ve avarifi bî pâyândır. Kütüb-i muteberenin müteleasina kâdir ve ilm-i tefsir ve hadisde mâhir ve fâzıl-ı danişmend ve cevelân-ı tâb-ı letâfet disârı ve şân-ı şeref şiârı nihâyette bülenddir. Zamânede hüsn-i ibâret ve lâtif istiârâtla inşâa-i dilküşa seyretmek isteyen Memâlik-i Osmânîye ve asâkir-i mansûre-i Sultâniye hakkında Tabâkatü'l- Memâlik tesmiye olunur kitâb-ı belagat nisâbını mütâlea kllsun ve elkab ve elfaz ve mâani kande olur görsün. Bir kitâb-l kemyâbdır ki imlâ ve inşâsı semt-i kadh ve ayıbdan muarrâ ve müberrâ olub elfaz-ı beligasına mâani-i bediasına münşiyân-ı menâşir-i dîvân-ı belagât...engüşt der dehân iderler" (Latifî, 1314, 336-337).

Belirtilmesi gereken diğer bir husus da Celâlzâde Mustafa Çelebi'nin ünlü Osmanlı tarihçisi Gelibolulu Mustafa Âlî üzerinde bıraktığı derin etkidir. Mustafa Âlî, Celâlzâde ile birlikte onun ardılı olup Küçük Nişancı olarak bilinen Ramazanzâde'yi her daim büyük bir minnet ve şükran duygusuyla anmıştır. Künhü'l-Ahbar'ı yazmakla onların manevi mirasçısı ve vekayinâme yazımınındaki halefi olan Mustafa Âlî, kırk yıl sonra bile onları genç yaşta tanımış olmakla övünüyordu:

“Bu hakîr ya'ni müellif-i kesirü't-taksîr gerek bunlar ile gerek Celâlzâde merhûmla niçe niçe ihtilât itmişizdür hüsn-i iltifâtlarından veled-i ma'nevî edindikleri rağbete yönmişiz hikmet hudânındır. Tevârih-i Âl-i Osman yazmada anlara sâlis olduk âkıbet Ramazanzâde merhûmun hanesini iştirâ eyleyüb gûyâ ki muhallefâtına vâris olduk” (Fleischer, 1996, 29-30).

Celâlzâde Çelebi dönemin kaynaklarının ortak anlatımına göre oldukça cömert ve kabiliyetli kişileri yetiştirmekle kendini vazifeli kılan bir insan idi. Divan edebiyatının büyük şairi Fuzuli dahi kendisine büyük bir muhabbet beslemiş, edebiyatımızın en güzide örneklerinden olan meşhur Şikayetnâmesini bizzat Celâlzâde Mustafa'ya hitaben yazmıştır. İkili arasında yalnız bir 
tanışıklık değil kuvvetli bir dostluk olduğu çok kolay anlaşılabilir. Şairin: "Gül-i hadika-i ikbal Mustafa Çelebi Kim oldu devlet-i kurbile kamkar kalem” diye methe başladığı Nişancı'yı çok sevdiği aşikardır (Karahan, 1995, 88). Diğer taraftan kendisinin Celâlzâde'nin himâyesini araması da doğaldır. Çünkü onun inşâda ustalığını en iyi devrin büyük münşîsi Nişancı Celâlzâde değerlendirebilirdi (İnalcık, 2003, 63). Yine asrın büyük şair ve de tezkire yazarı Aşık Çelebi meşhur Divân'ında Nişancı Beg Hazretleri'ne başlıklı şiirlerde kendisini çeşitli yönlerden metheder (Kılıç, 2013, 30-33). Mustafa Çelebi emeklilik yıllarında dahi kendi ismiyle anılan Nişanc1 Mahallesi'ndeki evinde şairleri toplamış, zamanını onları memnun etmekle geçirmiştir. Para almak amaciyla kendisine takdim edilen kasideler ve verilen paralar ciddi anlamda bir toplam oluşturmuştur (Uzunçarş111, 1990, 10). Diğer taraftan dönemin şuarâ tezkirelerindeki methiyeler de kendisinin cömertliğini ve yüce gönüllülügünü açıkça ortaya koymaktadır. Lâtifi, Kınalızâde Hasan Çelebi ve Bağdatlı Ahdî'nin eserlerinde onunla ilgili yazdığı satırlar önemlidir: "ârâste-i fünûn ve fezâil bir zat-ı kâmil ve fâzll-ı sahib-i cûd bir vücûd gelmemişdir ve mekârim-i ahlâkda ve hasail-i eş̧fakda ol zat-ı kerîmü's-sıfata adîl ve nazir olmamışdır" (Latifî, 1314, 335-336). “...hâtem-i zemân zat-ı meliki melekât-ı mahâsin-sıfat ile râdi'l-libân ve mekârim-i ahlâkla şerîkü'l-inân gamâm-ı in'âmı zemîn kılup...” (Kınalızâde Hasan Çelebi, 2009, 363). “...envâ-ı hayrât-ı bâ-berekâtı kemâl ile mevsûfdur" (Bağdatlı Ahdî, 2009, 41). Celâlzâde'nin yetiştirmelerinden olup sonraları nişancılığa kadar yükselen Sarhoş Abdi Çelebi, onun düşkünlere ve yoksullara yardımda bulunduğunu kaydeder. 1558 yılında İstanbul'a gelerek Eyüb'teki konağında kendisini ziyaret eden Mekke Emiri’nin elçisi Kutbüttin Mekkî kendisine birbirinden güzel methiyeler düzerek herkesin dilinde olan eli açıklığına ve de huyunun güzelliğine işaret etmiştir (Uzunçarş111, 1958, 402-403). Verilen bilgilerden, Celâlzâdede ortaya çıkan üstün özelliklerin ve çevresinin takdirini kazanmış olmasının ne kadar da tabii olduğu rahatlıkla anlaşılmaktadır.

Mustafa Çelebi inşâda ve resmi yazışmalarda büyük bir şan ve şöhret kazanmasının yanı sıra, şiirde de oldukça etkili fakat şöhret bulmamış bir şâirdi. Şair olarak yazdığı kasideleri Padişaha teslim ettiğinde hizmetten başka yirmi yük kadar da caize almıştı (Mehmed Süreyya, 1996, 1201). Şiirlerinde kullandığı mahlası Nişancı olup şiirlerinden seçilmiş birkaç örnek ise şunlardır:

Ey cebini mahv iden mâh-ı münîrün

Rûşen eyle mihr-i ruhsârunla gönlüm evin

Fenn-i aşka başladım dikkatle gördüm nice bâb

Metni derd-i faslı hicrân ile dolmuş bir kitab

Nedür ey dil bu âh u nâle 'ışk böyle fâş itmek

Sana mı kaldı ey dîde cihânı böyle yaş itmek

(Latifî, 1314, 337; Sehi Bey, 1325, 34; Beyâni, 2008, 210).

Koca Nişancı Celâlzâde'nin şimdiye kadar değinildiği vasıflarının yanında tarihçiler için en önemli tarafı şüphesiz kaleme aldığı değerli eserleridir. Osmanlı Tarihi’nin en parlak devrine ait yazdığı eserler, söz konusu döneme kaynak teşkil eden diğer eserlerin en değerlilerindendir. Elbette ki yazdıklarının bir bölümünün o dönemin siyasi şartları altında değerlendirilmesi gereklidir. Kendisi elli yılı aşkın bir süre devlet hizmetinde bulunmuş, tanık olduğu olayların niteliği ve de çağının dinamikleri tabii olarak yazdıklarını şekillendirmiştir. Yazının devamında Celâlzâde'nin eserleri hakkında toplu malumat verilecektir.

\section{Eserleri}

Tabakâtü'l- Memâlik ve Derecâtü'l- Mesâlik (Memleketlerin Tabakaları ve Mesleklerin 
Dereceleri): Celâlzâde bu eserini emekli olduktan sonra 964/1557 senesinde yazmıştır. Hem isim hem de içerik konusunda Klasik Arap Edebiyatı'nın etkisinde kalarak tarihsel gerçeklerle betimlemiş, Osmanlı Devleti'nin coğrafyasını anlatmayı amaç edinmiş görünmektedir. Eserine Memâlik ve Mesâlik kitaplarının şemasına uygun düşen kapsamlı bir fihrist de koymuştur (Demirtaş, 2009, 48). Eser otuz tabaka ve üç yüz yetmiş beş derece üzerine tertib olunmuştur. $\mathrm{Bu}$ otuz tabakanın yirmi dokuz tabakası saray, hazine, merkez teşkilatı, kapıkulu ocakları, geri hizmette müstahdem askeri ocaklar, donanma, eyaletler ile İstanbul'daki dini, ilmi ve içtimai tesisler ve saireye ait olup otuzuncu tabaka ise Kanuni Sultan Süleyman zamanındaki olaylar ve 1559 da Süleymaniye Camii inşaatının sonuna kadar gelmektedir. Fakat Tabakâtü'l- Memâlik'in baş tarafında fihrist halinde zikredilen ve büyük önemi olan yirmi dokuz tabakayı içeren cilt bugüne kadar görülmemiştir (Uzunçarş1l1, 1958, 404). Yazar, eseri telif sebebi olarak, kendi zamanına kadar yazılıp saraya takdim edilen tarihlerin devlet kurumları, idari ve askeri teşkilatlar, merkez ve civar bölgelere dair hiçbir ciddi malumat vermediklerini belirtir ve bu eksikliği gidermek istediğini yazar. Kanuni Dönemi'nde devletin ne şekilde genişlediği, memlekette ne gibi teşkilat ve de eserlerin vücuda getirildiğini gelecek nesillere öğretmenin tarihi bir vazife olduğuna da dikkat çeker (Celâlzâde Mustafa Çelebi, 2011, 13). Eserin Gelibolulu Âlî başta olmak üzere daha sonraki kronik ve tarihi eserlere de kaynak teşkil ettiği açıktır. Mustafa Çelebi bu eseri oldukça sanatlı, süslü bir üslupla kaleme almıştır. Zaman zaman şiirlerle de olayları besleyerek, kale ve çeşitli yapıların tasvirinde, resm-i geçit ve muharebelerin anlatılmasında yer yer hakikati gölgeleyecek derecede mübalağalı bir şekilde sanatını konuşturmuştur. Dönemin önemli tarihçilerinden Peçevî'ye göre bu eserini nazım ve nesirle Şehnâme olarak yazmıştır (Peçevi, 1283, 43). Eserle alakalı dönemin tezkire sahiplerinin görüşleri dikkate değerdir. Sehi Bey, tezkiresinde Celâlzâde'nin eserinde bir kalenin ismini zikrederken kullandığ sıfat ve secileri diğer bir kaleyi zikrederken tekrar etmediğine dikkat çeker ve onun ustalığını belirtir (Sehi Bey, 1325, 33). Kınalızâde Hasan Çelebi, Mustafa Çelebi'nin eserde kullandığı dili eleştirir ve gösterişli sözcükler kullanarak, mâna tarafının ihmal edildiğini belirtir (Kınalızâde Hasan Çelebi, 2009, 364). Yine diğer bir tezkire sahibi Beyanî de inşâsının gösterişli ve âmiyane elfâz olduğunu, üstâdâne olmadığını söyleyerek eleştiri getirir (Beyânî, 2008, 210). Esere yöneltilen çeşitli eleştirilere rağmen, şu noktayı önemle belirtmek gerekir: Elbette Celâlzâde, Sultan Süleyman'ın gücü ve adalet şemsiyesi altında olaylara yaklaşmıştır. Fakat bu durum eserin kıymetini gölgelememelidir. Tabakât, Sultan Süleyman Dönemi’nin en detaylı kaynaklarından birisidir. Son olarak Celâlzâde'nin bu eserinin bazı bölümlerine Fetihnâme-i Rodos, Mohaçnâme ve Fetihnâme-i Karaboğdan isimleriyle ayrı olarak rastlandığı da belirtilmelidir.

Selimnâme (Meâsir-i Selim Hânî): Celâlzâde Mustafa bu eserini 964/1557 senesinde nişanc1lıktan çekildikten sonra yetmiş yaşlarında yazmıştır. Selimnâme, Yavuz Sultan Selim'in şehzadeliğini, Trabzon Valiliği'nden itibaren vefâtına kadar olan gelişmeleri ve kazandığı başarıları içerir. Kendisi yazdıklarının büyük çoğunluğunu birinci el bir kaynak sayılan Veziriazam Pirî Mehmed Paşa'dan işitmiştir. Yirmi üç fasl'a ayrılmış olan eserin girişinde Celâlzâde kendi hayatından bahsetmektedir (Celâlzâde Mustafa Çelebi, 1990, 250). Bundan Selimnâme'nin Tabakatü'l-Memâlik'ten sonra bitirildiği ve Selim'i baba katili ithamından kurtarmak için yazılmış olduğu anlaşlabilir (Babinger, 1992, 114). Bununla birlikte, yazar tam bir Selim taraftarıdır. Eserde kullandığı üslup ise ağırdır. Yer yer tamamen Arapça veya Farsça yazılmış mektup ve şiirler bulunmaktadır. Divanda Reisülküttab ve Nişancı olarak hizmet vermiş olan Celâlzâde, bunu bir imtiyaz olarak addetmiş ve diğer yazarların bilmediği malumatı alarak eserine aktarmıştır. Bu vasıf da eseri diğerlerine nazaran oldukça kıymetli bir kaynak haline getirmektedir. Hacim bakımından diğer Selimnâmelere kıyasla geniş bir eserdir. Olayların genel sıralaması ve anlatımındaki yakın benzerlik Celâlzâde ile meşhur tarihçi Kemalpaşazâde'yi birbirine yakın- 
laştırmaktadır. Bu duruma göre Nişancı, Kemalpaşazâde' den kaynak ve stil yönünden istifade etmiştir. Diğer taraftan verilen malumat ve yararlanılan kaynaklar bakımından, yazarın kullandıkları ile Feridun Bey'in Münşeatü's-Selâtin'de kullandıkları birbiriyle benzerlik teşkil etmektedir. Bu da onun devlet dairesinde bulunmasından ötürü, devletin arşivini bir kaynak olarak kullandığı iddialarının doğru olduğunu ispatlar niteliktedir (Uğur, 1984, 407-408).

Mevaibü'l-Hallak fi Meratibi'l-Ahlâk (Ahlâkın Mertebesinde Allah'ın İhsanları): İyi ve kötü huyların fayda ve zararlarından bahsedilen bu eser elli altı bab ve bir hatime üzerine tertip edilmiş önemli bir ahlâk kitabıdır. Celâlzâde eserini emekliliğinden sonra yazarak Sultan Süleyman'a ithaf etmiş̧ir. Mevaibü'l- Hallak üç padişah yani Süleyman, Selim ve Murad tarafindan incelendiği için sonraları Enisü's-Selâtin diye meşhur olmuştur. Eserin mukaddimesinde esmâ- i hüsna şerhi ve hatimesinde Hazret-i Peygambere salavat yer alır (Bursalı Mehmed Tahir, 1342, 38).

Delâil-i Nübüvvet-i Muhammedî ve Şemail-i Fütüvvet-i Ahmedî (Peygamberler Tarihi): Eser, Molla Miskin diye meşhur olan Muhammed el Ferâhi'nin (XVI. yüzyılda yaşamış meşhur hadis alimi [ö.954/1547]. Herat'ta kadılık yapmış olmasının dışında hayatı hakkında bilgi yoktur, bk. Şenel, 2005, 259) siyer kitabı "Mearicü'n-Nübüvvet fi Medarici'l-Fütüvve” adlı Farsça eserinin tercümesidir. Celâlzâde Mearicü'n-Nübüvvet'i Nişancı bulunduğu sırada tercüme etmiş olup burada kendisine mahsus inşadaki kudret ve sanatını göstermiş ve kitabına bu ismi vermiştir. Eser bir mukaddime, dört rükün ve bir hatime üzerindedir. Birinci kısım; Nur-1 Muhammedî ve bunun bazı Peygamberlere intikali ile İsmail Peygamber'e ve Hz. Muhammed'e intikalini, İkinci kısım; Hz. Muhammed'in doğumundan bir peygamber olarak tebliğe memur olmasını, Üçüncü kısım; vahi, hicret ve miracı, Dördüncü kısım ise hicretten vefatlarına kadar olan olayları ve mucizeleri içermektedir (Uzunçarşı11, 1958, 412).

Hediyyetü'l-Müminîn (Müminlerin Armağanı): Celâlzâde'nin risale şeklinde, bazı hikayelerle, tevhidi, peygamber sevgisini, dört halifenin vasıflarını, güzel ahlakı, Allah'a içten bağlılığ ve en sonunda da Peygamberin torunları olan İmam Hasan ve Hüseyin haklarındaki hürmeti beyan ettiği kısmen mensur kısmen de manzum eseridir. Eser yirmi altı varak olup risalenin en sonunda "Nişanî hâkrah-ı Mustafadır" mısraı bulunmaktadır (Uzunçarşı11, 1958, 413).

Cevahirü'l- Ahbar fi Hasaili'l- Ahyar (İyiliklerin Cevherleri İyilerin Huyları): Arap edib ve müelliflerinden Ebu Hafs Saracüddin Ömer bin İbrahim el-Ensarî'nin Yusuf Peygamber kıssasına dair olan "zehrü'l- kimam fi kıssat-ı Yusuf aleyhisselatüvesselâm" adındaki on yedi meclis üzerine tertib edilen eserinin tercümesidir. Celâlzâde, Yusuf Hikayesi’nin Türk Dili’yle çoğunlukla manzum olarak yazıldığını, hikayenin mensur örneklerinin yaygın olmadığını belirterek eseri Arapça'dan Türkçe'ye tercümesinin sebebini açıklar. Sebeb-i te'lif kısmında bunu şöyle anlatır: "Elsine-i enâm da ol kissa-i pür hisse ekser tarz-ı nazm ile muvaşşah u ârâstedür. Türkî dilde neşr ile Kıssa-i Yusuf meşhur olmadığı eclden ol kitab-ı celilü'ş̧şân, Arabî'den Türkî dil ile terceme olınmağa cür'et olındı" (Baran, 2011, 14). Cevahirü'l- Ahbar tercümesi on yedi meclis yani on yedi kısım üzerinde tertip olunup her meclisin sonu manzumdur. Celâlzâde bu tercümeyi Kanuni Sultan Süleyman'ın oğlu Şehzade Selim nâmına tercüme etmiştir. Tercümenin son yaprağında ise Sultan Süleyman'ın mührü vardır. Tercümenin sonundaki tarih manzumesine bakılacak olursa tercüme 972/1565 senesinde tamamlanmıştır (Uzunçarş111, 1958, 413-415).

Kanunnâme: Celâlzâde'nin nişancılığı zamanında derlenen kanunları ihtiva etmektedir. Yaya, müsellem, yürük, voynuk kanunlarıyla çeltik kanunu ve tefrika edilmiş iki yüze yakın yeni veya değiştirilmiş kanunları içerir. Nişancı'nın eski ve yeni kanunları açıklamak ve değiştirmek suretiyle derlenen kanunlara ise Kanun-ı Cedid denilmektedir (Uzunçarşı11, 1958, 415).

Tarih-i Kale-i İstanbul ve Mâbed-i Ayasofya (Tuhfetü'l- Mülûk): Farsça'dan tercüme edilmiş 
küçük bir eser olup eserin içeriği şöyledir: Mukaddime Sultan Süleyman'ı medh-ü sena, huruf-1 hece tertibli bir kasideden bir ahbabının Farsça olarak vermiş olduğu bu risale tercümesi ve sonra Iustinianus Dönemi olayları, Ayasofya'nın planı, bununla ilgili imparatorun rüya görmesi, Ayasofya'nın kubbesi ve ziyneti, Baba Cafer'in medhi, imparatorun Ayasofya Camii mimarına gazap etmesi. Eserin fasılları arasında manzum parçalar da vardır. İsmail Hakkı Uzunçarşılı'ya göre 1752 tarihinde çoğaltılan nüshada Celâlzâde'ye dair kayıt bulunmadığı için bu esere şüpheyle yaklaşmak gerekir (Uzunçarş1l1, 1958, 416).

Mensur Şehnâme: Osmanlı Müelliflerinde başka bir kaynaktan alıntı yapılarak bu tercüme eser kendisine mal edilmektedir (Bursalı Mehmed Tahir, 1342, 39).

Münşeat: Yazarın münşeatı içeren bir mecmuası olduğu şüphesiz ise de toplu halde bir münşeata rastlandığına dair bilgi bulunmamaktadır (Uzunçarşılı, 1958, 417).

Divançe: Celâlzâde'nin bazı mecmua ve şuara tezkirelerinde nişanî mahlasıyla yazmış olduğu şiirler mevcuttur. Eserlerinin çoğunda kendi manzumeleri bulunan, bazı kaside ve gazelleri olduğu da bilinen yazarın bir divanı olduğuna dair ise kayıt bulunmamaktadır (Uzunçarşıll, 1958, 417).

\section{Sonuç}

Eserlerinden de anlaşılacağı üzere Celâlzâde, tarih ve ahlâk üzerine yaptığı çalışmalarla adından söz ettirmiş, haklı olarak büyük bir şöhret kazanmıştır. Tarih alanında yazdığı eserler dönemin en değerli kaynakları olma niteliğini halen korumaktadır. Kendisinin görevi gereği devlet işlerinin içinde olması nedeniyle verdiği bilgilerin özgünlüğü de açıktır. Tüm bunlar XVI. yüzyıl tarihçiliğinde Celâlzâde'ye seçkin bir yer sağlamıştır. Bir diğer açıdan kanun derlemeleriyle de dönemin bürokrasisi üzerinde ciddi etkilerde bulunmuş bir simadır. Osmanlı devleti'nde kanunların sahip olduğu bağımsız statünün en önemli göstergelerinden birisi, bunların Nişancı'nın kontrolü altında bulunmasıydı. Nişancı kanunlara tuğra koyma yetkisine sahip olduğu için, bir kanunun yürürlüğe girmesi de onun elinde idi. Yine bir kanunun yürürlülükte kalıp kalmama durumu veya çeşitli idari birimler tarafindan yayımlanan kanunların var olan kanun külliyatına uygun olup olmadığını belirleyen kişi de nişancılardı. Tüm bunlar Osmanlı siyasi literatürünün şekillenmesinde Nişancı'ların, bilhassa Celâlzâde'nin oynadığı mühim rolu göstermektedir. 


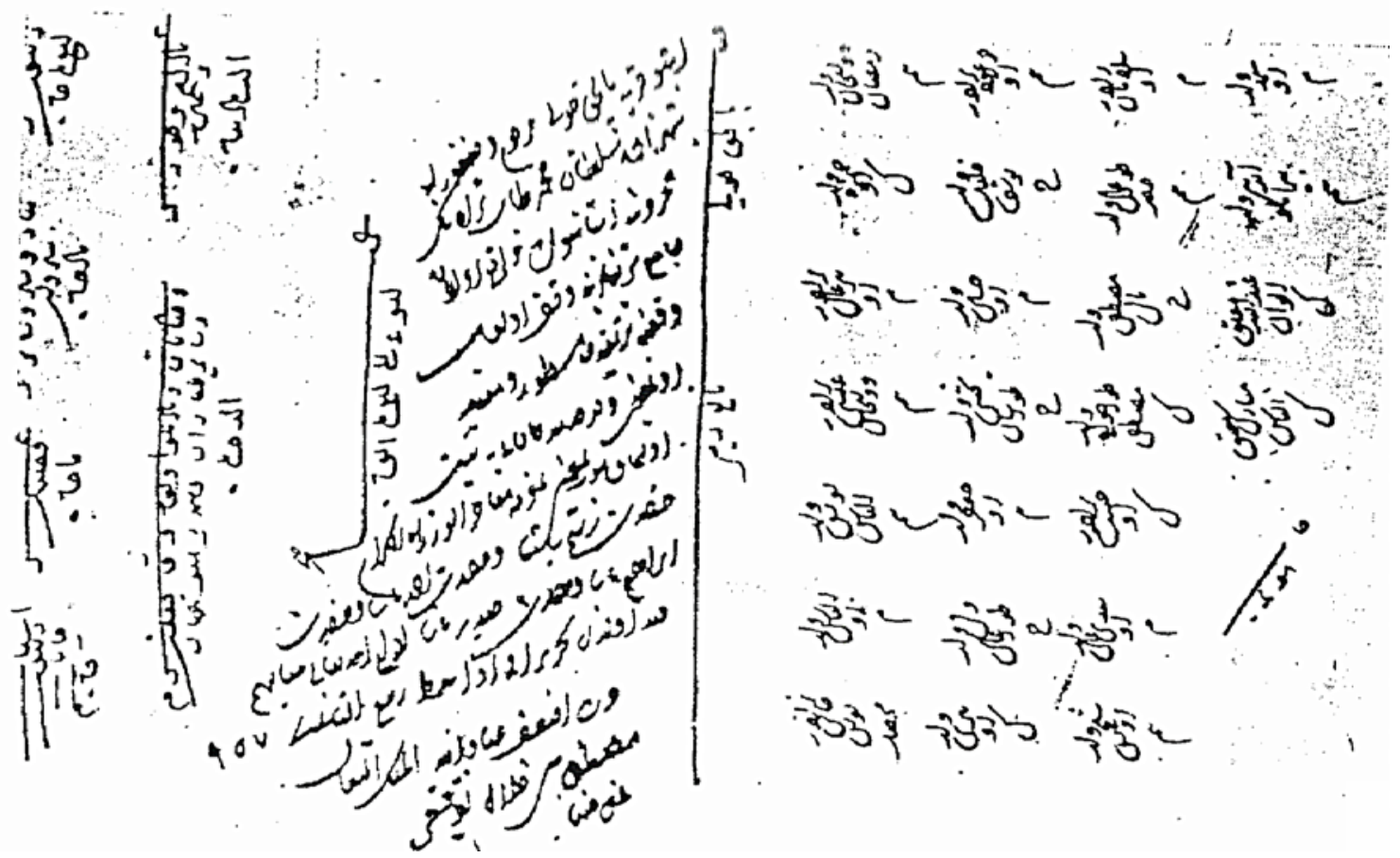

Fig. 1. Baş V. Ar. 996 No'lu Aydın Livası tahrir defterinde Celâlzâde Mustafa Çelebi'nin elyazısıyla tashihi. Akgündüz, 1994, 58.

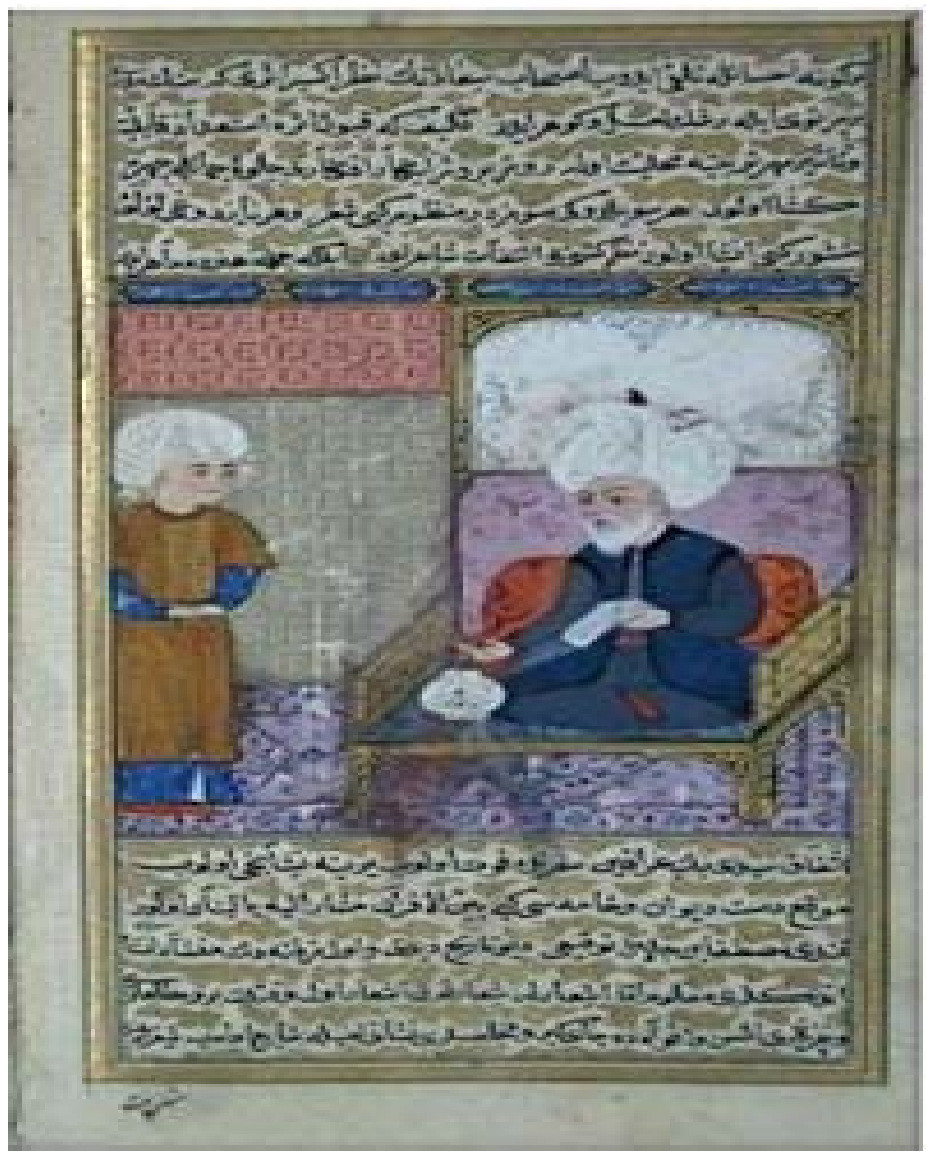

Fig. 2. Celālzāde Mustafa Çelebi; extract from Meşāiru’ş-Şu‘ārā. Ali Emiri, TR 772, 365, Yılmaz, $2006,251$. 


\section{KAYNAKÇA}

Ahmet Resmi Efendi. (1269). Halifetü'r-Rüesa. İstanbul: Takvimhâne-i Âmire.

Akgündüz, M. (1994). Osmanlı Devleti'nde Nişancıllk. Yayımlanmamış Yüksek Lisans Tezi. Marmara Üniversitesi, İstanbul.

Babinger, F. (1992). Osmanlı Tarih Yazarları ve Eserleri. Çev.: Coşkun Üçok. Ankara: Kültür Bakanlığı Yayınları.

Bağdatlı Ahdî. (2009). Gülşen-i Şu'arâ. Haz.: Süleyman Solmaz. Denizli: Kültür ve Turizm Bakanlığı Kütüphaneler ve Yayımlar Genel Müdürlüğ̈̈ Yayınları.

Baran, B. (2011). Celal-Zade Koca Nişancı Mustafa Çelebi, Cevahirü'l- Ahbar fi Hasaili'l- Ahyar. Yayımlanmamış Doktora Tezi. Dicle Üniversitesi, Diyarbakır.

Beyânî. (2008). Tezkiretü'ş-Şu'arâ. Haz.: Aysun Sungurhan Eyduran. Ankara: Kültür ve Turizm Bakanlığı Kütüphaneler ve Yayımlar Genel Müdürlüğü Yayınları.

Bursalı Mehmed Tahir. (1342). Osmanlı Müellifleri. Cilt I. İstanbul: Matbaa-i Âmire.

Celâl-Zâde Mustafa Çelebi. (1990). Selim-Nâme. Haz. Ahmet Uğur, Mustafa Çuhadar. Ankara: Kültür Bakanlığı Yayınları.

Celâlzâde Mustafa Çelebi. (2011). Tabakatü'l- Memâlik ve Derecâtü'l- Mesâlik (Kanunî'nin Tarihçisinden Muhteşem Çağ). Haz.: Ayhan Yılmaz. İstanbul: Kariyer Yayınları.

Danişmend, İ. H. (1948). İzahlı Osmanl Tarihi Kronolojisi. Cilt II. İstanbul: Türkiye Yayınevi.

Demir, M. (2014). “Makbûl İbrahim Paşa’nın Veziriazamlığı ve Mısır’daki Faaliyetleri”. MJH IV/1, 97-114.

Demirtaş, F. (2009). Celâl-Zâde Mustafa Çelebi, Tabakatü'l-Memâlik ve Derecâtü'l-Mesâlik. Yayımlanmamış Doktora Tezi. Erciyes Üniversitesi, Kayseri.

Derman, U. (2001). “Kanunî Devri'nde Yazı San'atımız”. Kanunî Armağanı, 269-289. Ankara: Türk Tarih Kurumu Yayınları.

Feridun Bey. (1265). Münşeatü's-Selâtin. Cilt II. İstanbul: Takvimhâne-i Âmire.

Fleischer, C. H. (1996). Tarihçi Mustafa Âlî-Bir Osmanlı Aydın ve Bürokratı. Çev.: Ayla Ortaç. İstanbul: Tarih Vakfı Yurt Yayınları.

Gelibolulu Mustafa Âlî. (2009). Künhü'l- Âhbâr. Rükn IV. Ankara: Türk Tarih Kurumu Yayınları.

Gökbilgin, T. (2001). “Celâl-Zâde”. İslâm Ansiklopedisi. Cilt III. Eskişehir: Milli Eğitim Basımevi.

İnalcık, H. (2003). Şâir ve Patron. Ankara: Doğu Batı Yayınları.

Karahan, A. (1995). Fuzulî: Muhiti, Hayatı ve Şahsiyeti. Ankara: Kültür Bakanlığı Yayınları.

Kerslake, C. J. (1993). "Celâlzâde Mustafa Çelebi”. Diyanet İslâm Ansiklopedisi. Cilt VII. İstanbul.

Kınalızâde Hasan Çelebi. (2009). Tezkiretü'ş-Şu'arâ. Haz.: Aysun Sungurhan Eyduran. Ankara: Kültür ve Turizm Bakanlığı Kütüphaneler ve Yayımlar Genel Müdürlüğü Yayınları.

Latifî. (1314). Tezkire-i Latifi. Dersaadet: İkdam Matbaası.

Mehmed Cemaleddin. (2003). Âyîne-i Zurefâ. Haz.: Mehmet Arslan. İstanbul: Kitabevi Yayınları.

Mehmed Süreyya. (1996). Sicill-i Osmanî. Haz.: Nuri Akbayar. Cilt IV. İstanbul: Tarih Vakfi Yurt Yayınları.

Pakalın, M. Z. (1983). Osmanlı Tarih Deyimleri ve Terimleri Sözlüğ̈̈. Cilt II. İstanbul: Milli Eğitim Bakanlığı Yayınları.

Peçevi. (1283). Tarih-i Peçevi. Cilt I. İstanbul: Matbaa-i Âmire.

Pıtcher, D. E. (2013). Osmanlı İmparatorluğu'nun Tarihsel Coğrafyası. Çev.: Bahar Tırnakçı. İstanbul: Yapı Kredi Yayınları Yayınları.

Sehi Bey. (1325). Tezkire-i Sehi. İstanbul: Amedi Matbaası.

Selânikî Mustafa Efendi. (1999). Tarih-i Selânikî. Haz.: Mehmet İpşirli. Cilt I. Ankara: Türk Tarih Kurumu Yayınları.

Şenel, A. (2005). "Molla Miskîn”. Diyanet İslâm Ansiklopedisi. Cilt XXX. İstanbul.

Uğur, A. (1984). "Celal-Zade Mustafa ve Selim-Nâmesi”. Ankara Üniversitesi Ilahiyat Fakültesi Dergisi, 
XXVI/I, 407-425. Ankara: Ankara Üniversitesi İlahiyat Fakültesi Yayınları.

Uğur, A. (2001). Osmanlı Siyaset - Nameleri. Milli Eğitim Bakanlığı Yayınları.

Uzunçarşı1ı, İ. H. (1988a). Osmanlı Devletinin Illmiye Teşkilâtı. Ankara: Türk Tarih Kurumu Yayınları.

Uzunçarşı11, İ. H. (1988b). Osmanlı Devletinin Merkez ve Bahriye Teşkilâtı. Ankara: Türk Tarih Kurumu Yayınları.

Uzunçarşılı, İ. H. (1958). "Onaltıncı Asır Ortalarında Yaşamış Olan İki Büyük Şahsiyet: Tosyalı Celâlzâde Mustafa ve Salih Çelebiler”. Belleten, XXII/87, 391-441. Ankara: Türk Tarih Kurumu Yayınları.

Uzunçarşı1l, İ. H. (1990). Kastamonu Meşâhiri. Haz.: Mustafa Eski. Ankara: Kastamonu Eğitim YüksekokuluYayınları.

Yılmaz, M. Ş. (2006). "Koca Nişancı" of Kanuni: Celalzade Mustafa Çelebi, Bureaucracy and "Kanun" in the reign of Suleyman The Magnificent (1520-1566). Yayımlanmamıs Doktora Tezi. Bilkent Üniversitesi, Ankara.

Woodhead, C. (2002). "Süleyman Üzerine Görüşler”. Kanuni ve Çağı-Yeniçağda Osmanlı Dünyası, 165 192. Ed.: Metin Kunt, \& Christine Woodhead. İstanbul: Tarih Vakfi Yurt Yayınları.

\section{İnternet Kaynakları}

Kılıç, F. (2013). Âşık Çelebi Dîvânı, http://ekitap.kulturturizm.gov.tr/dosya/1-213614/h/asikcelebidivanifilizkilic.pdf 
